\title{
The Effect of Trade Integration on Business Cycle Synchronization in East Asia
}

\author{
Vinh Thi Hong NGUYEN ${ }^{1}$, Thuy Thi Thanh HOANG ${ }^{2}$, Sang Minh NGUYEN ${ }^{3}$
}

Received: June 06, 2020 Revised: June 28, 2020 Accepted: July 09, 2020

\begin{abstract}
The paper aims to investigate the impact of trade integration on business cycle synchronization for the East Asian countries during 20052017 based on the endogeneity hypothesis of Optimum Currency Area criteria. We test the determinants of business cycles by calculating bilateral trade, financial integration, and business cycle synchronization. Applying the system Generalized Method of Moments for dynamic panel data models, the results show that business cycle synchronization is highly associated with trade and financial integration. These findings confirm the endogeneity hypothesis that more trade integration will mitigate asymmetric shocks, and have a positive impact on the business cycle synchronization. The increased trade intensity and financial linkage lead to more correlated business cycles in East Asia. Apart from trade and financial integration, the trade structure differential, monetary policy similarity also influence the business cycle comovement. The significantly negative impact of trade structure differential on business cycle synchronization suggests that countries with less similar structures are more likely to undergo asymmetric shocks. The results also indicate that monetary policy matters for output comovement. This study recommends that the East Asian countries should focus on bilateral trade as well as financial integration with each other to reap benefits from the integration process.
\end{abstract}

Keywords: Business Cycle Synchronization, Trade Integration, Optimum Currency Area, East Asia, Generalized Method of Moments

JEL Classification Code: E32, E44, F15

\section{Introduction}

In the literature, the Optimum Currency Area (OCA) formation has sparked considerable debate. The first perspective posits that countries have to fulfill the OCA criteria ex-ante. It means they are only allowed to participate when they meet currency union requirements. The second view is that a country can satisfy the OCA characteristics ex-post or after joining a currency union because increased

${ }^{1}$ First Author and Corresponding Author. Head of Department, Faculty of International Economics, Banking University Ho Chi Minh City, Vietnam [Postal Address: A2.906, Cantavil An Phu Apartment, An Phu Ward, District 2, Ho Chi Minh City, 700000, Vietnam] Email: vinhnth@buh.edu.vn

${ }^{2}$ Lecturer, Faculty of International Economics, Banking University Ho Chi Minh City, Vietnam. Email: thuyhtt@buh.edu.vn

${ }^{3}$ Associate Dean, Faculty of International Economics, Banking University Ho Chi Minh City, Vietnam. Email: sangnm@buh.edu.vn

(c) Copyright: The Author(s)

This is an Open Access article distributed under the terms of the Creative Commons Attribution Non-Commercial License (http://Creativecommons.org/licenses/by-nc/4.0/) which permits unrestricted noncommercial use, distribution, and reproduction in any medium, provided the original work is properly cited. intra-regional trade will help to enhance the business cycle synchronization (BCS). Following the latter perspective, the recent studies investigate the endogeneity of OCA by emphasizing the impact of OCA criteria on the synchronization of business cycles (Cerqueira \& Martins, 2009; Davis, 2014; Degiannakis, Duffy, Fillis \& Livada, 2016; Duval, Cheng, Oh, Saraf, \& Seneviratne, 2014; Frankel \& Rose, 1998; Imbs, 2004).

East Asia has become increasingly integrated through production, trade, and investments. In particular, after Asia's financial crisis, East Asian countries have launched the Chiang Mai Initiative that promotes greater intra-regional cooperation. Although East Asia is a crucial economic region, few empirical studies focus on monetary integration issues in an East Asian context. Most of the earlier research focuses on determinants of business cycles in the European area (Ahlborn \& Wortmann, 2018; Ahmed, Chaudhry, \& Straetmans, 2018; Artis, Fidrmuc, \& Scharler, 2008; Belke, Domnick, \& Gros, 2017; Böwer \& Guillemineau, 2006; Degiannakis et al., 2016; Lee, 2013; Monnet \& Puy, 2016). Besides, the empirical results of the impact of trade integration on business cycle synchronization are ambiguous. 
Hence, the paper contributes to the literature in several ways: First, based on Optimum Currency Area theory, we examine many aspects of OCA criteria, such as trade integration, financial linkage, trade structure differential, monetary policy similarity, financial crisis factors, and their impact on business cycle synchronization in East Asia. Second, this study conducts a dynamic panel data through the GMM model and calculates bilateral GDP correlation and other variables in the model of determinants of business cycle synchronization. The system GMM method helps to solve the endogeneity problem of the variables and fix other defects of the research model. We provide empirical evidence for the endogeneity hypothesis of Optimum Currency Area criteria.

The remainder of the study proceeds as follows. Section 2 summarizes previous studies on the OCA theory and the determinants of business cycles. The methodology is in Section 3, and Section 4 describes data variables. Section 5 shows empirical results. Section 6 includes conclusion and policy implications.

\section{Theoretical Background}

Theory of Optimum Currency Area is pioneered by Kenen (1969), McKinnon (1963), and Mundell (1961) indicates the crucial optimality criteria as price and wage flexibility, factor mobility, trade openness, and product diversification. The early contributions emphasize the key attributes of an OCA by which a region could overcome the costs of maintaining a common currency. Other researchers have noted and analyzed the internal conflicts and contradictions between these criteria and found out ways to reconcile these conflicts and bring them into harmony (Kunroo, 2015). Business cycle synchronization is deemed to be a key characteristic reconciling the above criteria.

The OCA theory has come back in the 1990s and shifted from the criteria to overcome the costs of maintaining a common currency to focusing more on the benefits of a currency area. Bearing in mind that the integration degree is an important characteristic of an OCA, the more integrated an economy becomes, the more it can gain, and the less it can lose from joining a currency union. The costs and benefits analysis is emphasized to find out an optimum degree of integration at which the benefits exceed the costs.

The benefits of a currency union can be obtained in the way that the distances between countries could be narrowed down by lowering transaction costs, removing market segmentation, eliminating exchange rate volatility, and rising price transparency. It thereby promotes trade among monetary union members. The benefits also involve the insulation from speculation bubbles. Mundell (1973) adjusted his view from stating that exchange rates to be used to absorb asymmetric shocks towards a view that exchange rate volatility becomes a target of destabilizing speculative movements which in turn results in asymmetric shocks under the condition of high capital mobility (Kunroo, 2015).

Among the new OCA theory, the endogeneity vs specialization hypothesis gains much attention. It throws light on the question of how trade integration affects the business cycles of the currency area members. However, this hypothesis is contradictory. From the theoretical perspective, the relationship between the two criteria - trade integration and correlation of business cycles - is ambiguous. For the specialization hypothesis, trade integration pushed by a common currency will make the member economy more specialized by its comparative advantage. The more specialized economy (less diversified) will be more vulnerable to industry-specific shocks, leading to divergent business cycles. With the endogeneity hypothesis, more trade integration will mitigate asymmetric shocks, thereby has a positive impact on the business cycle coherence.

With the traditional approach to OCA theory, an area needs to have optimality characteristics before forming a monetary union. But from the endogeneity hypothesis, the characteristics are endogenous. The endogeneity is found between international trade patterns and business cycles correlation. The causality in the traditional view has been reversed. The common currency will mitigate the asymmetric shocks through more trade integration. The empirical results from Frankel and Rose (1997) using a panel of twenty industrialized countries for thirty years data have shown that the international trade intensity has a strong positive and statistically significance on the correlation of economic activity. So, greater integration has led to more comovement of business cycles.

Krugman (1993) gave some implications about the relationship between trade integration and business cycles by pointing out with the case of the European Monetary Union that the combination of EMU will tend to produce some new stabilization problems at the regional level. European Community regions will tend to be more specialized. As this region becomes increasingly specialized, it will be vulnerable to industry-specific shocks. Borrowing Krugman's view, Fidrmuc (2001) stated considerable doubts as to the causal relationship between trade integration and the business cycles of countries related to Frankel and Rose (1997) research. Diverging expectations about the relationship evolve. Fidrmuc (2001) also notes Kenen's point of view that the business cycle correlation does not necessarily mean that asymmetric shocks are reduced.

Fidrmuc (2001) tested the endogeneity hypothesis of OCA criteria on a sample of OECD countries and concluded that the business cycles among OECD trading partners relate to intra- industry trade. The intra-industry trade integration leads to the diffusion of the demand shocks across the region. The research argued that the new structure of international trade leads to the business cycle synchronization. The 
endogeneity hypothesis of OCA criteria is also tested by other studies (Baxter \& Kouparitsas, 2005; Duval et al., 2014; Imbs, 2004; Nzimande \& Ngalawa, 2017). The findings from these studies are consistent with (Frankel \& Rose, 1997) suggesting that trade intensity has a positive impact on BCS. However, Abiad, Furceri, Kalemli-Ozcan, and Pescatori (2013); Calderón, Chong, and Stein (2007); and Shin and Wang (2004) find no or weaker effects of trade intensity on the synchronization of business cycles. Besides, Hye, Wizarat, and Lau (2016) indicate economic growth is positively affected by the individual trade indicator and composite trade openness index in the China context.

The previous studies also examine the impact of financial integration on BCS (Harding \& Pagan, 2006; García-Herrero \& Ruiz, 2008; Schiavo, 2008; Lee \& Azali, 2010; Jiang et al., 2019; Padhan \& Prabheesh, 2020). Morgan, Rime, and Strahan (2004) suggest that in a more financially integrated world institutions would decrease lending and reallocate the fund to others causing cycles to further diverge. KalemliOzcan, Sørensen, and Yosha (2003) find a negative impact of financial integration on business cycle co-movement while Padhan and Prabheesh (2020); Imbs (2006); and Artis, Fidrmuc, and Scharler (2008) finds a positive effect of financial integration on BCS. Bong and Premaratne (2020) suggest that raising financial integration will enhance the productive capacity of the economy. Regarding other OCA criteria, Padhan and Prabheesh (2020) provide a negative impact of the economic specialization dissimilarity on BCS. Nzimande and Nalawa (2017) identify that fiscal policy convergence and monetary policy similarity have a positive effect on business cycles while financial integration leads to diverging co-movement of business cycles. The conclusions are quite clear that a monetary union could be formed even if business cycles are not synchronized ex-ante as there would be business cycles co-movement ex-post. In addition, Dinh (2020) finds the inflation rate is positively related to economic growth, while Ngoc (2020) indicates the inflation is negative and asymmetric related to economic growth in the long run in the case of Vietnam.

Although the topic attracts considerable attention, empirical results on the endogeneity of the OCA criteria are ambiguous and inconclusive. The paper, thus, applies the dynamic panel data to investigate the relationship between trade integration, financial integration, monetary policy similarity, and synchronization of business cycles for East Asia.

\section{Methodology}

Following the approach of Imbs (2004); and Nzimande and Nalawa (2017),we explain business cycle synchronization by bilateral trade and other variables that discussed by the OCA literature:

$$
\begin{aligned}
Y_{i j, t} & =\alpha_{0}+\alpha_{1} y Y_{i j, t-1}+\alpha_{2} T R A D E_{i j}+\alpha_{3} T S C \\
& +\alpha_{4} F I N_{i j}+\alpha_{5} I N F_{i j}+\alpha_{6} C R I S I S+\varepsilon
\end{aligned}
$$

In the Eq. (1), ij denotes a country-pair in the time t. Where $y_{i j, t}$ is the bilateral business cycle synchronization. $T R A D E_{i j}$ is the bilateral trade intensity;TSDij is the trade structure differential; FINij is financial integration, INFLij is the inflation differential or monetary policy similarity, Crisis is the dummy variable controlling for the global financial crisis 2008.

We measure the business cycles synchronization as follows:

$$
y_{i j, t}=S D\left(\Delta Y_{i}-\Delta Y_{j}\right)
$$

where $\Delta Y_{i}$ and $\Delta Y_{j}$ are the real GDP of country $\mathrm{i}$ and $\mathrm{j}$ at time $\mathrm{t}$.

We use the ratio of bilateral exports as an indicator of bilateral trade integration as follows:

$$
T R A D E_{i j}=\frac{1}{T} \sum_{t=1}^{T}\left(\frac{e x_{i t}}{y_{i t}}+\frac{e x_{j t}}{y_{j t}}\right)
$$

The trade structure differential is constructed by

$$
T S D_{i j}=\frac{1}{T} \sum_{t=1}^{T}\left(\left|A_{i t}-A_{j t}\right|+\left|B_{i t}-B_{j t}\right|+\left|C_{i t}-C_{j t}\right|\right)
$$

where $A_{i j t}, B_{i j t}$, and $C_{i j t}$ denote the percent of agricultural trading, the percent of mining trading, manufacture trading respectively. The monetary policy similarity is calculated as follow:

$$
I N F_{i j}=\frac{1}{T} \sum_{t=1}^{T}\left(\pi_{i t}-\pi_{j t}\right)
$$

where $\pi_{i t}$ and $\pi_{j t}$ are the customer price index for each country pair.

We also use the M2 and GDP at a current price as an indicator of financial integration:

$$
F I N_{i t}=\frac{1}{T} \sum_{t=1}^{T}\left(\frac{M 2_{i t}}{y_{i t}}+\frac{M 2_{j t}}{y_{j t}}\right)
$$

We apply the dynamic panel data approach to estimate the parameters because GMM estimation allows choosing suitable variables for instrumenting and controlling for the potential endogeneity of all explanatory variables. Besides, 
GMM will not use any particular distributions of the error term and provides consistent estimates even if there is heteroscedasticity. We test the validity of instrument sets by the Hansen J-test and the absence of second-order serial correlation in the first differenced residuals by the ArellanoBond test.

\section{Descriptions of Variables and Data Sources}

In this study, we use a panel model for 13 East Asian countries (China, Japan, Korea, Brunei, Indonesia, Cambodia, Malaysia, Myanmar, Philippines, Thailand, Laos, Singapore, and Vietnam). All the data collected from the CEIC Database and the International Financial Statistics
(IFS). The summary of statistics is reported in Table 1. The figures show that business cycles coherence, trade intensity, financial integration, and monetary policy similarity are different among East Asian countries.

The correlation coefficients from Table 2 show that the correlations among variables are low. The variables of the study sample have a positive sign with business cycle synchronization, except the trade structure differential.

\section{Empirical Results}

Figure 1 and Figure 2 show the average annual trade, financial integration, and business cycle synchronization from 2005 to 2017 . The average yearly BCS decreases

Table 1: Variable summary

\begin{tabular}{|l|c|c|c|c|c|}
\hline \multicolumn{1}{|c|}{ Variables } & No of obs & Average & Std & Min & Max \\
\hline BCS $_{i j}$ & 1,014 & 0.002409 & 0.045505 & -0.140798 & 0.146 \\
\hline TRADE $_{i j}$ & 992 & 0.038204 & 0.054929 & 0.0000001 & 0.668183 \\
\hline TSD $_{i j}$ & 1,014 & 0.516888 & 0.348831 & 0.0099713 & 1.576942 \\
\hline FIN $_{i j}$ & 1,014 & 1.893356 & 0.703241 & 0.3822177 & 3.836473 \\
\hline INFL $_{i j}$ & 1,014 & 0.039416 & 0.050386 & 0.0002 & 0.3496 \\
\hline
\end{tabular}

Table 2: Correlation between variables

\begin{tabular}{|l|c|c|c|c|c|}
\hline \multicolumn{1}{|c|}{ Variables } & BCS $_{\mathbf{i j}}$ & TRADEij & TSD $_{\mathbf{i j}}$ & FINij & INFLij \\
\hline BCS $_{\mathrm{ij}}$ & 1 & & & & \\
\hline TRADE $_{\mathrm{ij}}$ & 0.0297 & 1 & & & \\
\hline $\mathrm{TSD}_{\mathrm{ij}}$ & -0.1495 & -0.152 & 1 & & \\
\hline $\mathrm{FIN}_{\mathrm{ij}}$ & 0.0865 & 0.2871 & -0.3748 & 1 & \\
\hline $\mathrm{INFL}_{\mathrm{ij}}$ & 0.0099 & -0.083 & 0.177 & -0.2537 & 1 \\
\hline
\end{tabular}

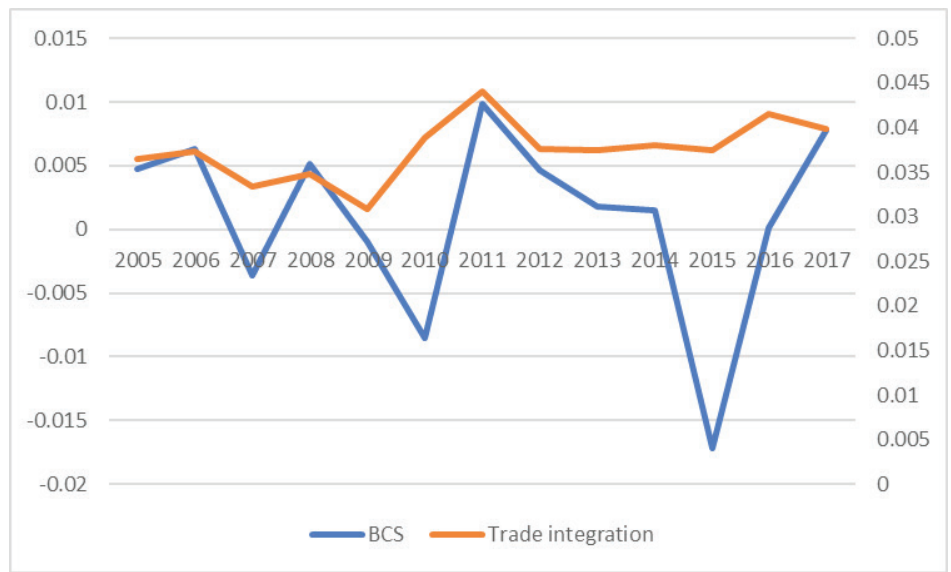

Figure 1: Average annual trade integration and BCS

Source: CEIC and IFS 


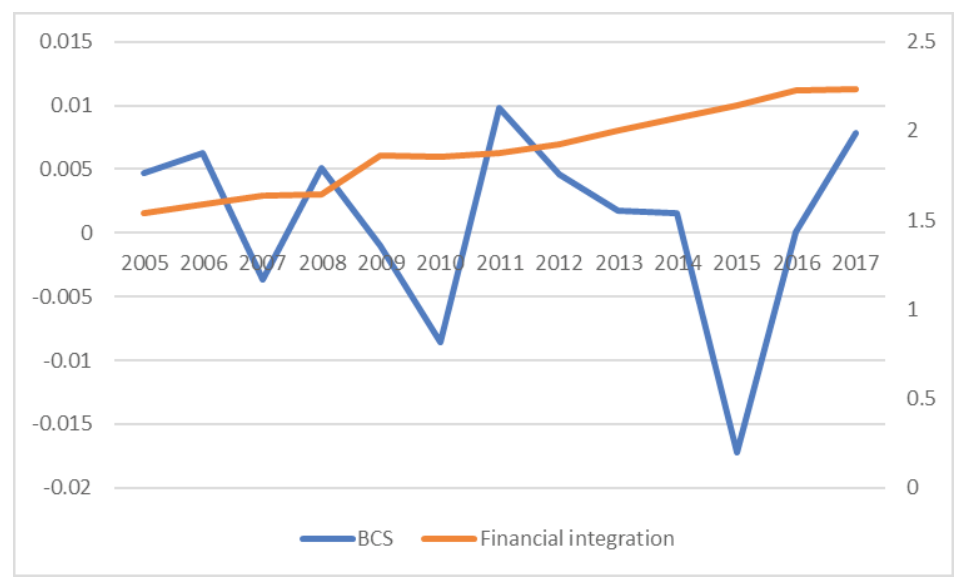

Figure 2: Average annual financial integration and BCS

sharply in 2010 and 2015 with -0.009 and -017 and increases peak in 2011 with 0.01 . It implies that business cycle synchronization is different among countries. From Figure 1 , the average annual trade integration has a similar trend compared with business cycles when it increases in 2011 and drops in 2009 and 2015. The average annual financial integration of East Asian countries trends to increase in the research period.

To test the stationary of the variables in the model, we employ the Dickey-Fuller Fisher Augmented tests. The null hypothesis for this test is that the panel data contain a unit root. The results obtained in Table 3 suggest that all variables have a p-value of less than 0.05 , for this reason, we reject the null hypothesis, and the data are stationary at their level form.

The results reported in Table 4 reflect that we fail to reject the null hypothesis of the validity of instruments and no serial correlation. The $\mathrm{AR}(2)$ and Hansen test results indicate that the study has no serial correlation and valid instruments. The p-value of Wald tests are smaller than $1 \%$, thus, all models are appropriate.

Table 4 includes the results of the determinants of the synchronization of business cycles. Columns from (1) to (6) indicate respectively the different specifications for the robustness of the estimations. We add an additional regressor in each column. The findings show that trade integration has a significant effect on business cycle coherence with a $1 \%$ level in all models. Our results support the endogeneity hypothesis, which explains that increased trade integration will mitigate asymmetric shocks, thereby having a positive impact on the business cycle coherence. The findings are also in line with previous studies (Frankel \& Rose, 1998; Imbs, 2004, and Duval et al., 2014). This implies that even a country that does not satisfy monetary union criteria ex-ante can be fulfilled ex-post because increased trade integration
Table 3: The unit root tests

\begin{tabular}{|l|c|c|}
\hline Variables & $\begin{array}{c}\text { Fisher type ADF } \\
\text { p-value }\end{array}$ & $\begin{array}{c}\text { Fisher type ADF } \\
\text { t-value }\end{array}$ \\
\hline BCS & 0.0000 & -15.5092 \\
\hline Trade & 0.0026 & -2.7898 \\
\hline TSD & 0.0000 & -8.4303 \\
\hline FIN & 0.0000 & -7.7793 \\
\hline INF & 0.0000 & -11.5009 \\
\hline Crisis & 0.0000 & -5.1844 \\
\hline
\end{tabular}

will enhance business cycle synchronization. In Model 5, we find that the effect of trade intensity on BCS is smaller in crisis times, compared with Model 4.

The results in Table 4 show that, not only the trade intensity, but also the trade structure differential, which has a strong negative impact on business cycle synchronization. This implies that countries with less similar structures are more likely to undergo asymmetric shocks. Contrary to Cerqueira and Martins (2009), Nzimande and Nalawa (2017), our findings show that the business cycle synchronization is positive and significantly affected by financial integration. The positive sign implies that increased financial integration leads to higher business cycle correlations, and the effect is bigger during the crisis period (Model 5). This result is consistent with that of Imbs (2004) and Kose et al. (2003). Apart from financial and trade intensity, monetary policy matters for output co-movement. In line with Frankel and Rose (1998), and Nzimande and Ngalawa (2017), we find that the inflation difference among East Asian countries has a positive and statistically significant impact on business cycle coherence. The findings show that countries should coordinate in monetary policy for enhancing business cycles. 
Table 4: System GMM estimation results for East Asia for the period 2005 - 2017

\begin{tabular}{|c|c|c|c|c|c|}
\hline BCS & Model 1 & Model 2 & Model 3 & Model 4 & Model 5 \\
\hline BCS(-1) & $\begin{array}{c}0.1057^{* * *} \\
(0.0053)\end{array}$ & $\begin{array}{c}0.1305^{\star * *} \\
(0.0060)\end{array}$ & $\begin{array}{c}0.1997^{* * *} \\
(0.0061)\end{array}$ & $\begin{array}{c}0.1311^{* * *} \\
(0.0085)\end{array}$ & $\begin{array}{c}0.1272^{* * *} \\
(0.0098)\end{array}$ \\
\hline Trade intensity & $\begin{array}{c}0.1268^{* * *} \\
(0.0107)\end{array}$ & $\begin{array}{c}0.0457^{* * *} \\
(0.0125)\end{array}$ & $\begin{array}{c}0.0083^{* * *} \\
(0.0094)\end{array}$ & $\begin{array}{l}0.084^{* * *} \\
(0.0079)\end{array}$ & $\begin{array}{c}0.0771^{* * *} \\
(0.0137)\end{array}$ \\
\hline $\begin{array}{l}\text { Structure } \\
\text { differential }\end{array}$ & & $\begin{array}{c}-0.017^{* * *} \\
(0.0010)\end{array}$ & $\begin{array}{c}-0.0057^{* * *} \\
(0.0014)\end{array}$ & $\begin{array}{c}-0.0118^{* * *} \\
(0.0026)\end{array}$ & $\begin{array}{c}-0.0101^{* *} \\
(0.0033)\end{array}$ \\
\hline $\begin{array}{l}\text { Finance } \\
\text { integration }\end{array}$ & & & $\begin{array}{c}0.0020^{* * *} \\
(0.0005)\end{array}$ & $\begin{array}{l}0.0024^{\star *} \\
(0.0010)\end{array}$ & $\begin{array}{l}0.0039 * * \\
(0.0014)\end{array}$ \\
\hline Inflation & & & & $\begin{array}{c}0.0602^{* * *} \\
(0.0098)\end{array}$ & $\begin{array}{c}0.0995^{\star * *} \\
(0.0125)\end{array}$ \\
\hline Crisis & & & & & $\begin{array}{c}0.0007 \\
(0.0011)\end{array}$ \\
\hline Constant & $\begin{array}{c}-0.0026^{\star * *} \\
(0.0007)\end{array}$ & $\begin{array}{c}0.00849^{* * *} \\
(0.0008)\end{array}$ & $\begin{array}{l}-0.0026^{*} \\
(0.0014)\end{array}$ & $\begin{array}{c}-0.0026^{* * *} \\
(0.0032)\end{array}$ & $\begin{array}{l}-0.0073^{*} \\
(0.0039)\end{array}$ \\
\hline Obs & 914 & 914 & 914 & 914 & 914 \\
\hline No. instruments & 68 & 68 & 67 & 66 & 64 \\
\hline No of groups & 78 & 78 & 78 & 78 & 78 \\
\hline AR2 & 0.100 & 0.146 & 0.271 & 0.176 & 0.183 \\
\hline Hansen test & 0.248 & 0.151 & 0.133 & 0.149 & 0.107 \\
\hline
\end{tabular}

Note: ${ }^{* *},{ }^{* *},{ }^{* *}$ and ${ }^{* *}$ present significance at $1 \%, 5 \%$ and $10 \%$ levels respectively. Standard errors in parentheses

\section{Conclusion and Policy Implications}

Using system GMM estimation for annual data from 2005 to 2017, this paper contributes to testing the endogeneity of the OCA theory based on a sample of 13 East Asian countries. We provide some evidence to confirm the endogeneity hypothesis that more trade integration will mitigate asymmetric shocks, and have a positive impact on the business cycle synchronization. Hence, our empirical results are consistent with the previous findings. The findings also show that type of trade has a negative effect on business cycle co-movement while monetary policy and financial integration has a positive effect on business cycles. The results suggest the East Asian countries should coordinate for trade, monetary policies, and financial flows to strengthen business cycle co-movements. We suggest that the East Asian countries should focus on bilateral trade as well as financial integration with each other to reap benefits from the integration process. Our further study will look at the value-add exported between countries and different capital flows to reexamine this research results.

\section{References}

Abiad, A., Furceri, D., Kalemli-Ozcan, S., \& Pescatori, A. (2013). Dancing together? Spillovers, common shocks, and the role of financial and trade linkages. In International Monetary Fund, World Economic Outlook 2013 (pp. 81-111). Washington, DC: International Monetary Fund.

Ahlborn, M., \& Wortmann, M. (2018). The core-periphery pattern of European business cycles: A fuzzy clustering approach. Journal of Macroeconomics, 55, 12-27. https://doi. org/10.1016/j.jmacro.2017.08.002.

Ahmed, J., Chaudhry, S. M., \& Straetmans, S. (2018). Business and financial cycles in the Eurozone: Synchronization or decoupling. Manchester School, 86(3), 358-389.

Artis, M. J., Fidrmuc, J., \& Scharler, J. (2008). The transmission of business cycles implications for EMU enlargement. The Economics of Transition, 16(3), 559-582. https://doi. org/10.1111/j.1468-0351.2008.00325.x

Baxter, M., \& Kouparitsas, M. A. (2005). Determinants of business cycle comovement: A robust analysis. Journal of Monetary Economics, 52(1), 113-157.

Belke, A., Domnick, C., \& Gros, D. (2017). Business cycle synchronization in the EMU: Core vs. periphery. Open Economies Review, 28(5), 863-892. https://doi.org/10.1007/ s11079-017-9465-9

Bong, A., \& Premaratne, G. (2019). The Impact of Financial Integration on Economic Growth in Southeast Asia. Journal of Asian Finance, Economics and Business, 6(1), 107-119. https:// doi.org/10.13106/jafeb.2019.vol6.no1.107 
Böwer, U., \& Guillemineau, C. (2006). Determinants of business cycle synchronisation across euro area countries. ECB Working Papers No. 587.

Calderón, C., Chong, A., \& Stein, E. (2007). Trade intensity and business cycle synchronization: Are developing countries any different? Journal of International Economics, 71(1), 2-21. https://doi.org/10.1016/j.jinteco.2006.06.001

Cerqueira, P. A., \& Martins, R. (2009). Measuring the determinants of business cycle synchronization using a panel approach. Economics Letters, 102(2), 106-108. https://doi.org/10.1016/j. econlet.2008.11.016

Davis, J. S. (2014). Financial integration and international business cycle co-movement. Journal of Monetary Economics, 64, 99111. https://doi.org/10.1016/j.jmoneco.2014.01.007

Degiannakis, S., Duffy, D., Filis, G., \& Livada, A. (2016). Business cycle synchronisation in EMU: Can fiscal policy bring membercountries closer? Economic Modelling, 52, 551-563. https:// doi.org/10.1016/j.econmod.2015.09.035

Dinh, D. V. (2020). Optimal Inflation Threshold and Economic Growth: Ordinal Regression Model Analysis. Journal of Asian Finance, Economics and Business, 7(5), 91-102. https://doi. org/10.13106/jafeb.2020.vol7.no5.091

Duval, R., Cheng, K., Hwa Oh, K., Saraf, R., \& Seneviratne, D., (2014). Trade integration and business cycle synchronization: A reappraisal with focus on Asia. IMF Working Papers, 14(52), 1. https://doi.org/10.5089/9781475522464.001

Fidrmuc, J. (2001). The endogeneity of Optimum Currency Area criteria, intraindustry trade and EMU enlargement. SSRN Electronic Journal. https://doi.org/10.2139/ssrn.1016024

Frankel, J. A., \& Rose, A. K. (1997). Is EMU more justifiable ex post than ex ante? European Economic Review, 41(3-5), 753760. https://doi.org/10.1016/S0014-2921(97)00034-2

Frankel, J.A., \& Rose, A. K. (1998). The endogenity of the Optimum Currency Area Criteria. The Economic Journal, 108(449), 1009-1025. https://doi.org/10.1111/1468-0297.00327

García-Herrero, A., \& Ruiz, J. M. (2008). Do trade and financial linkages foster business cycle synchronization in a small economy? BBVA Working Papers No. 0810.

Harding, D., \& Pagan, A. (2006). Synchronization of cycles. Journal of Econometrics, 132(1), 59-79. https://doi.org/10.1016/j. jeconom.2005.01.023

Hye, Q. M. A., Wizarat, S., \& Lau, W. Y. (2016). The Impact of Trade Openness on Economic Growth in China: An Empirical Analysis. Journal of Asian Finance, Economics and Business, 3(3), 27-37. https://doi.org/10.13106/jafeb.2016.vol3.no3.27.

Imbs, J. (2004). Trade, finance, specialization, and synchronization. Review of Economics and Statistics, 86(3), 723-734. https://doi. org/10.1162/0034653041811707

Imbs, J. (2006). The real effects of financial integration. Journal of International Economics, 68(2), 296-324. https://doi. org/10.1016/j.jinteco.2005.05.003
Jiang, W., Li, Y., \& Zhang, S. (2019). Business cycle synchronisation in East Asia: The role of value-added trade. The World Economy, 42(1), 226-241. https://doi.org/10.1111/twec.12668

Kalemli-Ozcan, S., Sørensen, B. E., \& Yosha, O. (2003). Risk sharing and industrial specialization: Regional and international evidence. American Economic Review, 93(3), 903-918. https:// doi.org/10.1257/000282803322157151

Kenen, P. (1969). The theory of optimum currency areas: An eclectic view (R.A. Mundell and A.K. Swoboda). University of Chicago Press.

Krugman, P. (1993). Lessons of Massachusetts for EMU. In F. Torres \& F. Giavazzi (Eds.), Adjustment and Growth in the European Monetary Union (pp. 241-266). Cambridge University Press. https://doi.org/10.1017/CBO9780511599231.016

Kunroo, M. H. (2015). Theory of Optimum Currency Areas: A Literature Survey. Review of Market Integration, 7(2), 87-116. https://doi.org/10.1177/0974929216631381

Lee, G. H. Y., \& Azali, M. (2010). The endogeneity of the Optimum Currency Area criteria in East Asia. Economic Modelling, 27(1), 165-170. https://doi.org/10.1016/j.econmod.2009.08.004

Lee, J. (2013). Business cycle synchronization in Europe: Evidence from a dynamic factor model. International Economic Journal, 27(3), 347-364.

McKinnon, R. I. (1963). Optimum Currency Areas. The American Economic Review, 53(4), 717-725.

Monnet, E., \& Puy, D. (2016). Has globalization really increased business cycle synchronization? Banque de France Working Papers No. 592.

Morgan, D. P., Rime, B., \& Strahan, P. E. (2004). Bank integration and State business cycles. The Quarterly Journal of Economics, 119(4), 1555-1584. https://doi.org/10.1162/0033553042476161

Mundell, R. A. (1961). A Theory of Optimum Currency Areas. The American Economic Review, 51(4), 657-665.

Mundel, R. (1973). A plan for a European currency. In H. Johnson \& A. Swoboda (Eds.), The Economics of Common Currencies (pp.143-173), London, UK: Goerge Allen \& Unwin Ltd.

Ngoc, B. H. (2020). The Asymmetric Effect of Inflation on Economic Growth in Vietnam: Evidence by Nonlinear ARDL Approach. Journal of Asian Finance, Economics and Business, 7(2), 143149. https://doi.org/10.13106/jafeb.2020.vol7.no2.143.

Nzimande, N. P., \& Ngalawa, H. (2017). The endogeneity of business cycle synchronisation in SADC: A GMM approach. Cogent Economics \& Finance, 5(1). https://doi.org/10.1080/2 3322039.2017.1358914

Padhan, R., \& Prabheesh, K. P. (2020). Business cycle synchronization: Disentangling direct and indirect effect of financial integration in the Indian context. Economic Modelling, 85, 272-287. https://doi.org/10.1016/j.econmod.2019.10.010

Schiavo, S. (2008). Financial integration, GDP correlation and the endogeneity of Optimum Currency Areas. Economica, 75(297), 168-189. https://doi.org/10.1111/j.1468-0335.2007.00598.x

Shin, K., \& Wang, Y. (2004). Trade integration and business cycle co-movements: The case of Korea with other Asian countries. Japan and the World Economy, 16(2), 213-230. https://doi. org/10.1016/S0922-1425(03)00028-8. 